\title{
FcyRllla receptor polymorphism influences NK cell mediated ADCC activity against HIV
}

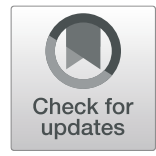

Sneha Pramod Talathi', Nawaj Najir Shaikh', Sudhanshu Shekhar Pandey', Vandana Ashish Saxena', Megha Sunil Mamulwar ${ }^{2}$ and Madhuri Rajeev Thakar ${ }^{1 *}$

\begin{abstract}
Background: HIV-specific Antibody Dependent Cell Cytotoxicity (ADCC) has shown to be important in HIV control and resistance. The ADCC is mediated primarily by natural killer cell activated through the binding of FcyRllla receptor to the Fc portion of antibody bound to the antigen expressed on the infected cells. However, no data is available on the influence of the polymorphism in FcyRllla receptor on HIV-specific ADCC response.

Methods: The Sanger's method of sequencing was used to sequence the exon of FcyRllla receptor while the ADCC activity was determined using NK cell activation assay. The polymorphism in FcyRllla receptor was assessed in HIVinfected Indian individuals with or without HIV-specific ADCC antibodies and its influence on the magnitude of HIVspecific ADCC responses was analyzed.

Results: Two polymorphisms: V176F (rs396991) and Y158H (rs396716) were observed. The Y158H polymorphism is reported for the first time in Indian population. Both, V176F (VN genotype) ( $p=0.004)$ and $\mathrm{Y} 158 \mathrm{H}$ (Y/H genotype) $(p=0.032)$ were found to be significantly associated with higher magnitude of HIV-specific ADCC response.

Conclusion: The study underscores the role of polymorphism in the FcyRIlla receptor on HIV-specific ADCC response and suggests that the screening of the individuals for FcyRllla-V176F and Y158H polymorphisms could be useful for prediction of efficient treatment in monoclonal antibody-based therapies aimed at ADCC in HIV infection.
\end{abstract}

Keywords: FcyRIIla-V176F polymorphism, FcyRllla-Y158H polymorphism, NK cells, ADCC, HIV

\section{Background}

Antibody dependent cell mediated cytotoxicity (ADCC) has shown to be associated with slower disease progression in Human Immunodeficiency Virus (HIV) infection [1-5]. The RV144 HIV vaccine trial has shown the correlation between lower infection rates and higher ADCC responses among vaccine recipients [6], highlighting the importance of ADCC responses in HIV protection. The ADCC is mediated primarily by natural killer (NK) cells through binding of the FcyRIIIa (CD16a) receptor with the Fc portion of the antibodies bound to the specific antigen expressed on the target cells. This binding initiates secretion of granzyme and perforin by NK cells resulting in the lysis of the target cell [7]. Thus, for strong ADCC responses; binding affinity of Fc $\gamma$ RIIIa

\footnotetext{
*Correspondence: mthakar@nariindia.org; mthakar@icmr.org.in

${ }^{1}$ Department of Immunology, National AIDS Research Institute, Plot No. 73,

G-Block, MIDC, Bhosari, Pune, Maharashtra 411026, India

Full list of author information is available at the end of the article
}

receptor and the Fc portion of the antibody is important $[8,9]$ and the polymorphic changes in this receptor are likely to affect the binding affinity of the FcyRIIIa receptor which might influence the ADCC activity [10-12]. Single nucleotide polymorphism (SNP) of Fc receptor gene of FcyRIIIa - V158F or V176F is known to result in low functioning receptor with phenylalanine $(\mathrm{F})$ and high functioning receptor with valine (V) [13, 14]. Populations like Dutch, [15] Sami, Norwegian, [16] Japanese, [14] African American, [12] British, and northern Indian [17] have shown this polymorphism at 158 amino acid position while Asian Indian [13], Malaysian [5], Chinese [18], Korean [19], Thais [20] etc. have shown this polymorphism at 176 position. The V158F polymorphism was found to be associated with augmented ADCC response to rituximab, an anti-cancer monoclonal therapeutic antibody in in-vitro experiments, suggesting that the individuals expressing at least one valine at amino acid position 158 in FcyRIIIa might show better

(c) The Author(s). 2019 Open Access This article is distributed under the terms of the Creative Commons Attribution 4.0 International License (http://creativecommons.org/licenses/by/4.0/), which permits unrestricted use, distribution, and 
rituximab-mediated ADCC [14, 21]. This polymorphism is in the exon 4 and is reported to alter the protein confirmation and thus influences binding affinity of FcyRIIIa and $\mathrm{FC}$ region of antibodies involved in $\mathrm{ADCC}[14,21]$. However, no information is available about this polymorphism in HIV infection and about its influence on the HIV-specific ADCC responses. Therefore in the present study, the presence of polymorphism in FcyRIIIa receptor was assessed by sequencing the exon 4 of FcyRIIIa receptor and the association of this polymorphism with the HIV-specific ADCC responses was determined. Our study population showed $\mathrm{F}$ to $\mathrm{V}$ transition at 176 amino acid position when the sequences were compared with the reference sequence from UCSC browser. Additionally, another polymorphism was observed at amino acid position 158, resulting in a substitution of tyrosine to histidine $(\mathrm{Y} 158 \mathrm{H})$. Both the polymorphisms observed to influence HIV-specific ADCC activity. Additionally Y158H has shown possibility of association with HIV acquisition.

\section{Methods \\ Study participants}

Study participants were identified from individuals followed up regularly at outpatient clinics of National AIDS Research Institute. Sixty-three HIV infected (42 female/21 male) ART naive individuals at various stages of HIV disease and 67 HIV uninfected healthy controls (HCs) (26 female/41 male) were enrolled in the study.

\section{ADCC (NK cell activation) assay}

The anti-HIV ADCC activity in the blood samples of the study participants was determined using NK cell

activation assay. The CD107a and IFN- $\gamma$ expression by activated NK cells were used as surrogate markers for HIV-specific stimulation of NK cells in presence of autologous antibodies as described previously [4]. Briefly, the autologous NK cells from sodium-heparinized fresh whole blood from a study participant were stimulated with HIV-1C envelope peptides (Env-C) (obtained from NIH AIDS Reference Reagent Program; Catalogue No. 9499) at a final concentration of $1 \mu \mathrm{g} / \mathrm{ml} /$ peptide in the presence of brefeldin A (Sigma, $10 \mu \mathrm{g} / \mathrm{ml}$ ), monensin (BD Biosciences, $0.68 \mu \mathrm{l} / \mathrm{ml}$ ) and anti-CD107a APC Cy7 (clone H4A3; from Biolegend, San Diego, CA). The whole blood stimulated with purified anti-CD16 antibody (clone-3G8, $2.5 \mu \mathrm{g} / \mathrm{ml}$ ) was used as a positive control and whole blood without stimulation was used as negative control. The plate was incubated for $5 \mathrm{~h}$ at $37^{\circ} \mathrm{C}$ in $5 \% \mathrm{CO}_{2}$ incubator. After incubation, $\mathrm{CD}^{-}$ CD56 ${ }^{\mathrm{dim}}$ NK cells were gated and analyzed for the expression of intracellular IFN- $\gamma$ and surface CD107a using fluorescent tagged antibodies [CD3 PerCP: (clone-SK7), CD56 PE-Cy7: (clone-HCD56), and CD107a APC-H7:
(clone-H4A3) (all from Biolegend), and IFN- $\gamma$ APC: (clone-B27) (BD Biosciences)]. The gating strategy is shown in Fig. 1a and d; (a) Lymphocytes were gated based on forward (FSC) and side scatter plot (SSC) and (b) NK cells were identified as $\mathrm{CD} 3^{-} \mathrm{CD} 56^{\text {dim }}$ cells and were assessed for either $\mathrm{CD} 107 \mathrm{a}$ or IFN $\gamma$ expression or dual expression. The percentage of activated NK cells as a marker of ADCC activity was represented as the sum of the percentage of activated NK cells, expressing only CD107a or IFN- $\gamma$, or both CD107a and IFN- $\gamma$ (Fig. 1c, d) [3]. The response observed in negative (unstimulated whole blood) control was subtracted from respective Env-C stimulated response. The criteria for responders were i) the total percentage of CD107a and IFN- $\gamma$ expressing (activated) NK cells was more than three times the percentage of activated NK cells from the negative control of the respective sample and ii) the individuals showing ADCC response above the mean plus two standard deviations (mean $+2 \mathrm{SD}$ ) response observed in HIV uninfected healthy controls. The mean NK cell activation shown by HIV uninfected healthy individuals for HIV-1 envelope $C$ was $0.64 \%$ (range: $0.00-2.95 \%$ ) and no healthy control showed ADCC against HIV-1 Env C above the cut off value.

\section{Genotyping for FcyRllla receptor}

Genomic DNA was extracted from peripheral blood using commercially available kit (QIAGEN, Inc., Valencia, CA) as per the manufacturer's instructions and used for genotyping of FcyRIIIa receptor. Purity of eluted DNA was checked using Nanodrop (ND-1000). The purified DNA was further used for PCR amplification of FCGR3A gene using specific primers of exon 4 (Forward primer: 5'-ATGGCAAAGGCAGGAAGTAT - 3', Reverse primer: 5' - CAACTTCCCAGTGTGATTGC-3') as reported previously [14]. The amplification conditions were: Initial denaturation at $95^{\circ} \mathrm{C}$ for $2 \mathrm{~min}$, followed by 35 cycles at $95^{\circ} \mathrm{C}$ for $30 \mathrm{~s}, 57^{\circ} \mathrm{C}$ for $30 \mathrm{~s}$, and $72^{\circ} \mathrm{C}$ for $30 \mathrm{~s}$, and final extension at $72^{\circ} \mathrm{C}$ for $7 \mathrm{~min}$. Amplified product of $218 \mathrm{bp}$ was confirmed on 1\% Agarose gel using $100 \mathrm{bp}$ ladder. PCR amplicon was purified using high prep PCR clean up kit (Magbio Genomics Inc.). After the cleanup, PCR products were denatured to single stranded DNA using formamide. Purified DNA product was sequenced using BigDye Terminator v3.1 cycle sequencing kit (Applied Biosystems, Foster City, CA) as per the manufacturer's instructions. ABI $\mathrm{PRISM}^{\circ} 310$ Genetic Analyzer (Thermo Fisher Scientific) was used for sequencing of desired product and results obtained were aligned against reference sequence from UCSC genome browser (NM_001127593.1) using SeqScape v2.6 and its protein sequence then matched and analyzed for polymorphism using MEGA6 software. 


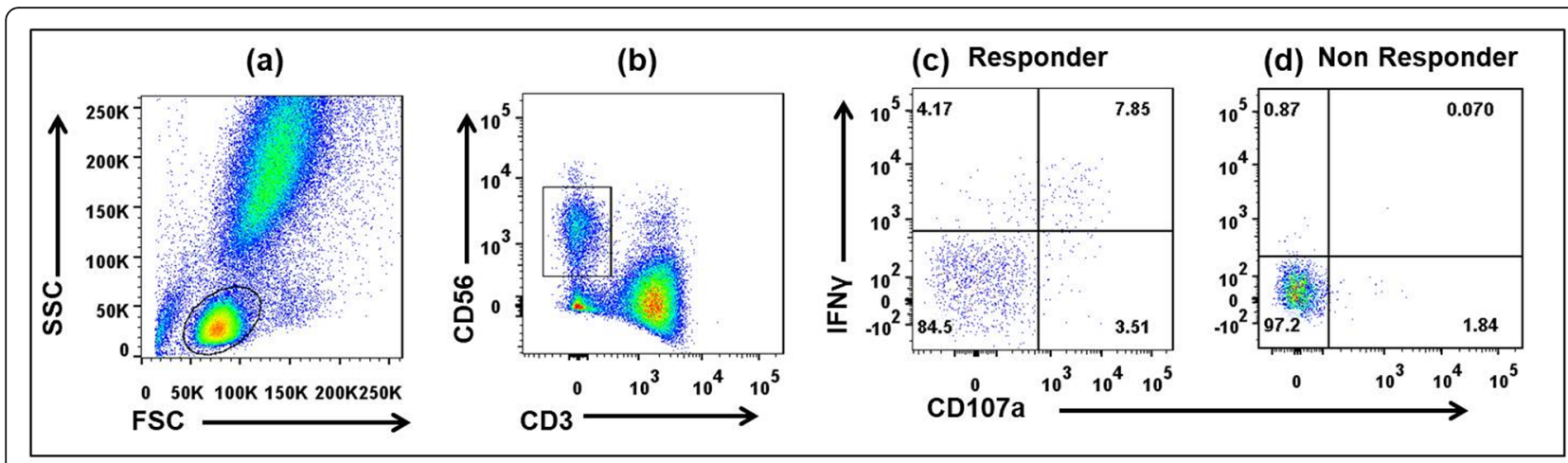

(e)

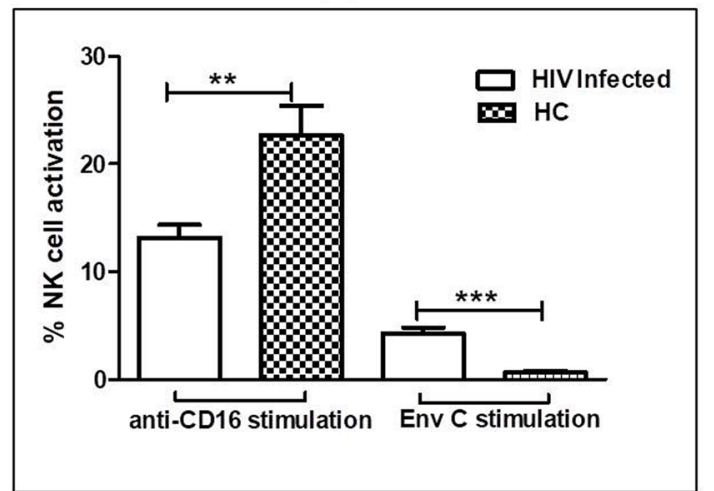

(f)

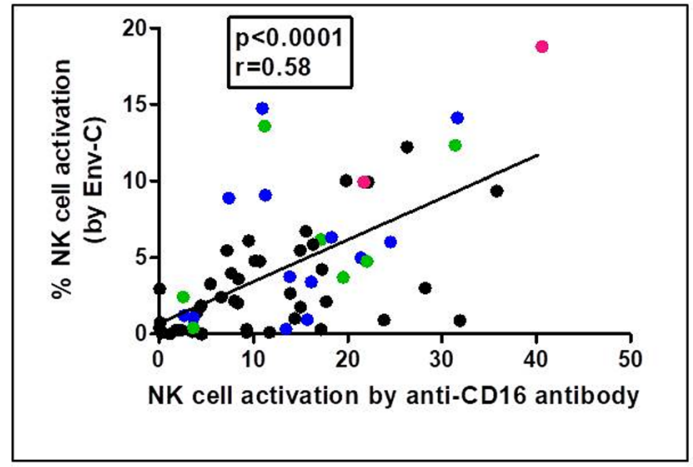

Fig. 1 Anti-HIV ADCC measured by NK cell activation (the sum of the percentage of activated NK cells, expressing only CD107a or IFN- $\mathrm{y}$, or both CD107a and IFN- $\gamma$ ) in study participants. a-d: Flow cytometry plots showing the gating strategy used a Lymphocytes were gated based on FSC and SSC and $\mathbf{b}$ NK cells were identified as CD3-CD56+ cells and were assessed for CD107a or IFNy expression or dual expression. Figures C and d shows representative plots showing NK cell activation observed in c HIV-1 Env-C responder and $\mathbf{d}$ HIV-1 Env-C non-responder e Bar graph shows \% NK cell activation by anti-CD16 antibody and HIV-1 Env-C stimulation in HIV infected individuals and healthy controls (HC) f Scatter plot shows correlation between \% NK cell activation by anti-CD16 antibody ( $\mathrm{X}$ axis) and Env-C stimulation (Y axis) (Spearman $r$ test) The FcyRllla genotypes associated with HIV-specific ADCC response have been identified as Green dots (VN genotype), Blue dots (Y/H genotype) and red dots (VN-Y/H genotype)

\section{Statistical analysis}

Statistical analyses were performed by using GraphPad Prism, version 5.0 (GraphPad software, San Diego, CA, USA). ANOVA-Bonferroni's Correction test and twotailed non parametric t-test (Mann Whitney) were used to determine the influence of genotypes on the magnitude of ADCC response. Genotype and allele frequencies of the FcyRIIIa within the study groups were compared using chi-square goodness-of-fit test or Fisher's exact test as applicable. The correlation between the frequencies of anti-CD16 antibody activated NK cells by and Env-C stimulation was assessed by Spearman $\mathrm{r}$ test. $P$ values $<0.05$ were considered significant.

\section{Results}

\section{Study population}

Sixty three HIV infected and 67 HIV uninfected healthy individuals were enrolled in the study. The mean age of HIV infected individuals was 39 years (range 27-54), the mean CD4 count was 594 cells per $\mu \mathrm{l}$ (range 56-1583) and the mean viral load was 97,062 RNA copies per ml (range $0-1,475,011$ ). The mean age of $\mathrm{HC}$ was 32 years (range 18-52). All the study participants were age matched and were of same ethnic background.

\section{HIV-specific ADCC responses}

$\mathrm{HIV}$-specific NK cell activation in presence of anti-HIV antibodies was used as a surrogate marker for HIV-specific ADCC response by number of studies [3, 4, 22-26]. Fifty seven percent (36/63) of HIV infected individuals showed Env-C specific NK cell (ADCC) response with a mean magnitude of $4.30 \%$ (range $0.0-18.80$ ). No association of NK cell activation was observed with either CD4 count or viral loads. (Data not shown) The functionality of NK cells is known to be compromised in HIV infection [27, 28]. Therefore the analysis of NK cell activation after anti-CD16 stimulation in HIV infected and uninfected study participants was also carried out. It showed significantly lower anti-CD16 mediated NK cell activation in HIV infected individuals (mean: 13.16\%; range 0.0-40.62) as compared to the response observed in uninfected controls (mean: 22.66\%; range 0.42-43.01; $p=0.0018$ ). (Fig. 1e) In HIV infected individuals, the anti-CD16 activated NK cell frequencies correlated positively with HIV-Env stimulated NK cell 
frequencies in presence of autologous anti-HIV antibodies indicating that the individuals showing ADCC responses had potent NK cells. $\left(p<0.0001, \mathrm{r}^{2}=0.36\right)$ (Fig. 1f).

\section{Identification of polymorphisms}

Two polymorphisms were found in a $218 \mathrm{bp}$ amplified PCR product. The earlier reported polymorphism at amino acid position 176 of FcyRIIIa receptor [12-14, 29, 30] was also observed in the Indian population. This polymorphism resulted in substitution of phenylalanine to valine at position 176 (V176F) (i.e. thymine (T) to guanine (G) transition) (NCBI dbSNP database accession number: ss2137543814). Another polymorphism was observed at nucleotide position 472 (at position 1,615,544,806 on chromosome 1/ 627 mRNA position) where transition from thymine ( $\mathrm{T})$ to cytosine $(\mathrm{C})$ resulted in tyrosine to histidine at 158 amino acid position (Y158H) (NCBI dbSNP database accession number: ss2137543815).

\section{Genotype and allele frequencies in HIV infected and uninfected study participants}

The genotypes $(\mathrm{V} / \mathrm{V}, \mathrm{V} / \mathrm{F}, \mathrm{F} / \mathrm{F}, \mathrm{Y} / \mathrm{Y} \& \mathrm{Y} / \mathrm{H})$ and allele frequencies $(\mathrm{V}, \mathrm{F}, \mathrm{Y} \& \mathrm{H})$ for the both polymorphisms are given in Table 1a, b. The analysis of genotype and allele frequencies showed significantly lower frequencies of $\mathrm{Y} / \mathrm{H}(\mathrm{Y} 158 \mathrm{H}$ polymorphism) genotype and $\mathrm{H}$ allele in
HIV infected study participants as compared to HCs. (Fisher's exact test: $p<0.0001 \& \mathrm{p}<0.0001$ respectively; Table 1b) None of the study participants showed CC $(\mathrm{H} / \mathrm{H})$ genotype at 158 amino acid position in case of Y158H polymorphism.

\section{Env-C specific ADCC response and FcyRIlla genotypes in HIV infected individuals}

The magnitude of Env-C specific ADCC response (\% activated NK cells after HIV-Env $C$ stimulation in presence of autologous anti-HIV antibodies) was found to be significantly higher in individuals with $\mathrm{V} / \mathrm{V}$ genotype (ANOVA Bonferroni's Correction test) ( $p=0.004$; Fig. 2a) as compared to the individuals with either $\mathrm{V} / \mathrm{F}$ or $\mathrm{F} / \mathrm{F}$ genotype. Similarly in case of $\mathrm{Y} 158 \mathrm{H}$ SNP, the individuals with the $\mathrm{Y} / \mathrm{H}$ genotype showed significantly higher magnitude of ADCC responses as compared with the individuals with the $\mathrm{Y} / \mathrm{Y}$ genotype $(p=0.032$; Fig. 2a). Since both the polymorphisms showed significant influence on ADCC responses the combined effect of the dual polymorphism on the magnitude of ADCC response was assessed using ANOVA-Bonferroni's Correction test and significantly higher magnitude of ADCC responses was observed in case of $\mathrm{V} / \mathrm{V}-\mathrm{Y} / \mathrm{H}$ genotype combination though only two individuals showed this genotype combination ( $p=0.001$, Fig. $2 \mathrm{~b})$. In this study,

Table 1 Frequency distribution of genotypes/allele in the study groups

\begin{tabular}{|c|c|c|c|c|}
\hline \multirow{2}{*}{$\begin{array}{l}\text { a. Genotype (VF variants) } \\
526 \text { T/G (V176F) }\end{array}$} & \multirow{2}{*}{$\begin{array}{l}\text { HIV infected } \\
N=63(\%)\end{array}$} & \multirow{2}{*}{$\begin{array}{l}\mathrm{HC} \\
N=67(\%)\end{array}$} & \multicolumn{2}{|c|}{ HIV infected vs HC } \\
\hline & & & $p$ value & OR $(95 \% \mathrm{Cl})$ \\
\hline$\Pi(F / F)$ & $19(30.16)$ & $23(34.33)$ & 1.00 & Reference \\
\hline $\mathrm{TG}(\mathrm{V} / \mathrm{F})$ & $36(57.14)$ & $34(50.75)$ & 0.56 & $0.78(0.36-1.68$ \\
\hline $\mathrm{GG}(\mathrm{VN})$ & $08(12.70)$ & $10(14.93)$ & 1.00 & $1.03(0.34-3.14$ \\
\hline \multirow[t]{2}{*}{ Allele (V176F) } & \multirow{2}{*}{$\begin{array}{l}\text { HIV infected } \\
N=126(\%)\end{array}$} & \multirow{2}{*}{$\begin{array}{l}\mathrm{HC} \\
N=134(\%)\end{array}$} & \multicolumn{2}{|c|}{ HIV infected vs HC } \\
\hline & & & $p$ value & OR (95\% Cl) \\
\hline$T(F)$ & $74(58.73)$ & $80(59.70)$ & 1.00 & Reference \\
\hline $\mathrm{G}(\mathrm{V})$ & $52(41.27)$ & $54(40.30)$ & 0.90 & $1.04(0.63-1.71)$ \\
\hline \multirow{2}{*}{$\begin{array}{l}\text { b. Genotype (YH variants) } \\
428 \mathrm{~T} / \mathrm{C}(\mathrm{Y} 158 \mathrm{H})\end{array}$} & \multirow{2}{*}{$\begin{array}{l}\text { HIV infected } \\
N=63(\%)\end{array}$} & \multirow{2}{*}{$\begin{array}{l}\mathrm{HC} \\
\mathrm{N}=67(\%)\end{array}$} & \multicolumn{2}{|c|}{ HIV infected vs HC } \\
\hline & & & $p$ value & OR (95\% Cl) \\
\hline$\pi(Y / Y)$ & 48 (76.19) & $23(34.33)$ & 1.00 & Reference \\
\hline $\mathrm{TC}(\mathrm{Y} / \mathrm{H})$ & $15(23.81)$ & $44(65.67)$ & $<0.0001$ & $0.16(0.07-0.35$ \\
\hline $\mathrm{CC}(\mathrm{H} / \mathrm{H})$ & $0(0)$ & $0(0)$ & - & - \\
\hline \multirow[t]{2}{*}{ Allele (Y158H) } & \multirow{2}{*}{$\begin{array}{l}\text { HIV infected } \\
N=126(\%)\end{array}$} & \multirow{2}{*}{$\begin{array}{l}H C \\
N=134(\%)\end{array}$} & \multicolumn{2}{|c|}{ HIV infected vs HC } \\
\hline & & & $p$ value & OR $(95 \% \mathrm{Cl})$ \\
\hline$T(Y)$ & $111(88.10)$ & $90(67.16)$ & 1.00 & Reference \\
\hline$C(H)$ & $15(11.90)$ & $44(32.84)$ & $<0.0001$ & $3.62(1.89-6.92$ \\
\hline
\end{tabular}

a: Frequency distribution of V176F and Y158H polymorphisms in HIV infected vs HIV uninfected healthy control groups. Presence of TT (F/F) for TG (V/F), GG (V/V) genotypes, $T$ for $\mathrm{G}$ allele was taken as reference group for statistical analysis

b: Frequency distribution of $\mathrm{Y} 158 \mathrm{H}$ polymorphism in HIV infected vs healthy control groups. Presence of TT (Y/Y) for TC (Y/H), CC (H/H) genotypes, T for C allele was taken as reference group for statistical analysis

Fisher's exact test was applied. $\mathrm{N}=$ number of subjects; $(\%)=$ frequency of genotypes/alleles, $\mathrm{OR}=\mathrm{Odds}$ ratio; $\mathrm{Cl}=$ Confidence Interval. The results with significance are shown in bold 

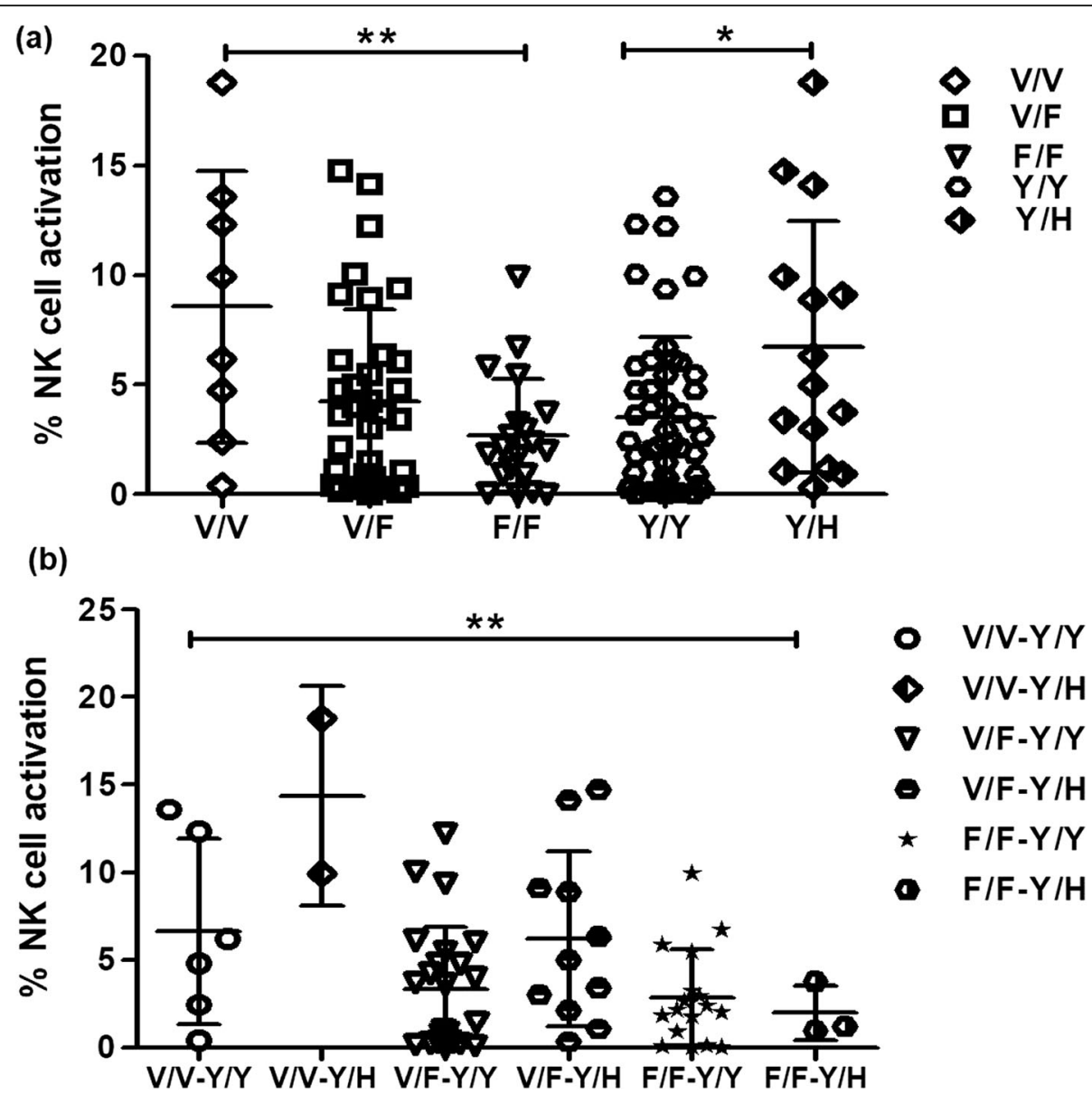

Fig. 2 Variation in the magnitude of ADCC response with the different genotypes. Vertical scatter plot depicts a \% NK cell activation in $V / N-V / F-F /$ $F \& Y / Y-Y / H$ genotypes in HIV infected study group (Bonferroni's multiple comparison of ANOVA for VN-V/F-F/F genotypes and Mann Whitney ttest for $Y$ and $Y / H$ genotypes), The * indicates $p<0.05$ and ** indicates $p<0.01 \mathbf{b} \%$ NK cell activation showed by the individuals showing different genotype combination (ANOVA-Bonferroni's Correction test and ** indicates $p<0.01$ )

when the association of anti-CD16 responses (baseline NK cell functionality) was compared with anti-HIV ADCC responses, results show that the individuals with the $\mathrm{V} / \mathrm{V}-\mathrm{Y} / \mathrm{H}$ genotype (shown as red dots in Fig. 1f) have both higher anti-CD16 and anti HIV-1 ADCC responses.

However, significant difference was not found in the number of ADCC responders according to their genotypes (V/V or V/F or F/F or Y/Y or Y/H). Since the presence of one "V" had the highest frequency in our study population, the number of ADCC responders carrying at least one "V" allele was compared to those with the number of responders with FF allele however; there was no significant difference between the genotypes of ADCC responders vs non responders. $(p>0.05)$.

\section{Discussion}

The genetic variants of FcyRIIIa receptor in HIV infected and uninfected Indian population and the association of these genotypes with the HIV-1 Env-C specific
ADCC activity in infected individuals were analyzed in this study. Two SNPs at amino acid positions 176 and 158 resulting in replacement of phenylalanine to valine and tyrosine to histidine respectively were observed. The V176F polymorphism has already been reported in the various populations whereas to best of our knowledge, the $\mathrm{Y} 158 \mathrm{H}$ polymorphism has been reported for the first time in Indian population. The frequency of FF genotype in the healthy controls in our study is $34.33 \%$ which was different from the frequencies reported in South Indian population [31]. This could be due to the differences in ethnicity since our study participants are mostly from Maharashtra, Western India. Similar differences in the $\mathrm{V} / \mathrm{V}-\mathrm{V} / \mathrm{F}-\mathrm{F} / \mathrm{F}$ genotype frequencies have been reported in Japanese populations also [32-34]. Both these SNPs were found to be associated with higher Env-C specific ADCC response supporting previous observation of association of the $\mathrm{V} / \mathrm{V}$ genotype in F176 V polymorphism with ADCC response $[14,21]$ and additionally showed association of the Y158H SNP with higher ADCC 
response. Previous studies have shown the association of high affinity CD16 receptor polymorphism with the clinical response of rituximab antibody in various lymphomas [35-37]. To best of our knowledge, this is the first report showing association of CD16 polymorphism with HIV specific ADCC response. The CD16 mediated ADCC activity is governed by NK cells [25]. NK cell are known to be functionally compromised in HIV infection $[27,28]$. The association between the anti-CD16 mediated NK cell activation and HIV-1 Env C specific response in this study although expected, confirms that the ADCC response require binding to efficient NK cells and also underscore the importance of the affinity of the binding of Fc portion of antibody with FcyRIIIa (CD16a) receptor. Also it was observed that the individuals with the $\mathrm{V} / \mathrm{V}$ and/or $\mathrm{Y} / \mathrm{H}$ genotype have both higher antiCD16 and anti HIV-1 ADCC responses hence it can be argued that the polymorphism in FcyRIIIa receptor might influence the binding of the Fc receptor of antiHIV antibody and FcyRIIIa receptor on NK cells and thus in turn the magnitude of anti-HIV ADCC response. The FcyRIIIa receptor and Fc portion of the antibody bind to each other through a hydrogen bonding between the carbonyl group of Val 176 in FcyRIIIa and nitrogen of Gly236 in Fc [14]. It is possible that the strength of this binding is affected due to the structural difference caused by the amino acid substitution (Valine is substituted by Phenylalanine) which might have resulted in weak binding and less potent or no ADCC response. Similar possibility can be argued with the $\mathrm{Y} 158 \mathrm{H}$ polymorphism. The ADCC could also be mediated by monocytes or neutrophils [22]. In this study, however the ADCC responses governed by these cells are not assessed. It might be possible that the individuals with $\mathrm{Y} / \mathrm{H}$ or $\mathrm{F} / \mathrm{F}$ or $\mathrm{Y} / \mathrm{H}$ genotype could still show ADCC responses governed by these cells. However since the NK cells are the prime cells showing ADCC [4], the contribution of ADCC mediated by monocytes or neutrophils could be marginal.

The HIV disease progression has been shown to be associated with polymorphism in host genes such as HLA, CCR5, SDF-1, KIR, TRIM5 $\alpha$ and the ABOBEC3 etc. [38-41]. The V176F polymorphism was not found to be associated with HIV-1 infection which was in the line with the previous reports showing absence of association between this polymorphism (V176F) and HIV infection $[10,18]$. In contrast Poonia et al and others have reported that a high affinity allele V/V of FCGR3A gene is a risk factor for HIV-1 infection and disease progression [30, 42]. Racial differences resulting in different genetic makeup could be one of the likely reasons contributing to these contrasting reports.

The predominance of $\mathrm{Y} / \mathrm{Y}$ genotype in HIV infected study participants in this study might indicate the probability of $\mathrm{Y} / \mathrm{Y}$ genotype as a risk factor for HIV infection among Indians. The population variability of both these SNPs could be the major source for the variability and thus the association between these SNPs and HIV infection could be confirmed on larger sample size only when the true association could be assessed.

However, the observation that the $\mathrm{Y} / \mathrm{H}$ genotype was associated with higher magnitude of HIV-1 specific ADCC response and association of $\mathrm{Y} / \mathrm{Y}$ (not $\mathrm{Y} / \mathrm{H}$ ) genotype with HIV infection might raise an interesting possibility that the NK cell activation in HIV exposed but seronegative (ESN) individuals could be one of the factor for resistance to HIV acquisition. Indeed a report on ESN has shown risk of HIV acquisition with reduced NK cytotoxicity [43]. It would be interesting to study whether ESN also have $\mathrm{Y} / \mathrm{H}$ genotype.

\section{Conclusion}

The present study describes two new findings: (a) the positive influence of the $\mathrm{V} 176 \mathrm{~F}$ and $\mathrm{Y} 158 \mathrm{H}$ polymorphisms on Env-C specific ADCC response, and (b) association of HIV infection and $\mathrm{Y} 158 \mathrm{H}$ polymorphism. The ADCC response could be used as an important parameter of control over HIV and associated cancers where the monoclonal antibody based therapies might be used. In such situations, the genotyping carried out before such therapy will help in predicting the therapeutic efficiency. Additionally, modulation of broadly successful monoclonal antibodies by specific amino acid substitutions would be a useful approach to enhance FcyRIIIa binding and NK mediated ADCC response.

\section{Abbreviations}

ADCC: Antibody dependent cell mediated cytotoxicity; Env-C: HIV-1C envelope peptides; ESN: HIV exposed but seronegative individuals;

FSC: Forward Scatter; HCs: Healthy controls; HIV: Human Immunodeficiency Virus; NK cells: Natural killer cells; SNP: Single nucleotide polymorphism; SSC: Side Scatter

\section{Acknowledgements \\ The authors thank the study subjects for their participation in this study. The authors thank Dr. RR Gangakhedkar, Ex Director-in-Charge of NARI for re- quired support. We also thank to the staff of Departments of Immunology and Virology for providing the CD4 count and plasma viral load data. Depart- ment of Molecular Biology is acknowledged for their help in sequencing of samples.}

\section{Authors' contributions}

SPT performed the research, data analyses, and wrote the manuscript. MRT designed the study and reviewed and finalized the manuscript. WS helped in designing the experiments and reviewed the manuscript. NNS helped in the PCR assay standardization. SSP helped in analyzing the sequencing data. MSM contributed clinical information and collection of the samples for the study.

\section{Funding}

The investigators thank the University Grants Commission (UGC), Government of India for supporting Ms. Sneha Talathi with CSIR-UGC-NET fellowship. The study was funded through institutional funding. The funding bodies do not have any role in the design of the study and collection, analysis, and interpretation of data and in writing the manuscript. 


\section{Availability of data and materials}

The sequences are submitted to GenBank and are available in GenBank with accession number MG460484 - MG460567 and MH590780 - MH590835.

\section{Ethics approval and consent to participate}

The study design was approved by an institutional ethics review board of National AIDS Research Institute (NARI/EC Protocol No.: 2012-06). All study participants provided written informed consent before the collection of blood samples for participation in the study. The study did not involve any vulnerable population.

\section{Consent for publication}

Not Applicable.

\section{Competing interests}

The authors declare no conflict of interest.

\section{Author details}

'Department of Immunology, National AIDS Research Institute, Plot No. 73, G-Block, MIDC, Bhosari, Pune, Maharashtra 411026, India. ${ }^{2}$ Department of Epidemiology, National AIDS Research Institute, Pune 411026, India.

Received: 4 April 2019 Accepted: 29 November 2019

Published online: 16 December 2019

\section{References}

1. Forthal DN, Landucci G, Daar ES. Antibody from patients with acute human immunodeficiency virus (HIV) infection inhibits primary strains of HIV type 1 in the presence of natural-killer effector cells. J Virol. 2001;75(15):6953-61.

2. Baum LL, Cassutt KJ, Knigge K, et al. HIV-1 gp120-specific antibodydependent cell-mediated cytotoxicity correlates with rate of disease progression. J Immunol. 1996;157(5):2168-73.

3. Kulkarni A, Kurle $\mathrm{S}$, Shete A, et al. Indian long-term non-progressors show broad ADCC responses with preferential recognition of V3 region of envelope and a region from tat protein. Front Immunol. 2017;8:5.

4. Chung AW, Rollman E, Center RJ, et al. Rapid degranulation of NK cells following activation by HIV-specific antibodies. J Immunol. 2009;182(2): 1202-10.

5. Wren LH, Chung AW, Isitman G, et al. Specific antibody-dependent cellular cytotoxicity responses associated with slow progression of HIV infection. Immunology. 2013;138(2):116-23.

6. Haynes BF, Gilbert PB, McElrath MJ, et al. Immune-correlates analysis of an HIV-1 vaccine efficacy trial. N Engl J Med. 2012;366(14):1275-86.

7. Overbaugh J, Morris L. The antibody response against HIV-1. Cold Spring Harb Perspect Med. 2012;2(1):a007039.

8. Parren PW, Warmerdam PA, Boeije LC, et al. On the interaction of IgG subclasses with the low affinity Fc gamma Rlla (CD32) on human monocytes, neutrophils, and platelets. Analysis of a functional polymorphism to human IgG2. J Clin Invest. 1992;90(4):1537-46.

9. Warmerdam PA, van de Winkel JG, et al. A single amino acid in the second Ig-like domain of the human Fc gamma receptor II is critical for human IgG2 binding. J Immunol. 1991;147(4):1338-43.

10. Forthal DN, Landucci G, Bream J, et al. FcgammaRlla genotype predicts progression of HIV infection. J Immunol. 2007;179(11):7916-23.

11. Koene HR, Kleijer M, Algra J, et al. Fc gammaRIlla-158V/F polymorphism influences the binding of lgG by natural killer cell Fc gammaRIlla, independently of the Fc gammaRllla-48L/R/H phenotype. Blood. 1997;90(3): 1109-14.

12. Wu J, Edberg JC, Redecha PB, et al. A novel polymorphism of FcgammaRIlla (CD16) alters receptor function and predisposes to autoimmune disease. J Clin Invest. 1997;100(5):1059-70.

13. Chong KT, Ho WF, Koo SH, et al. Distribution of the FcgammaRllla 176 FN polymorphism amongst healthy Chinese, Malays and Asian Indians in Singapore. Br J Clin Pharmacol. 2007;63(3):328-32.

14. Oboshi W, Watanabe T, Matsuyama Y, et al. The influence of NK cellmediated ADCC: structure and expression of the CD16 molecule differ among FcgammaRIlla-V158F genotypes in healthy Japanese subjects. Hum Immunol. 2016;77(2):165-71.

15. van Sorge NM, van der Pol WL, Jansen MD, et al. Severity of Guillain-Barre syndrome is associated with Fc gamma receptor III polymorphisms. J Neuroimmunol. 2005;162(1-2):157-64.
16. Torkildsen O, Utsi E, Mellgren SI, et al. Ethnic variation of Fc gamma receptor polymorphism in Sami and Norwegian populations. Immunology. 2005;115(3):416-21.

17. Milicic A, Misra R, Agrawal S, et al. The F158V polymorphism in FcgammaRIIIA shows disparate associations with rheumatoid arthritis in two genetically distinct populations. Ann Rheum Dis. 2002;61(11):1021-3.

18. Weis JF, McClelland RS, Jaoko W, et al. Short communication: Fc gamma receptors Illa and IIla genetic polymorphisms do not predict HIV-1 disease progression in Kenyan women. AIDS Res Hum Retrovir. 2015;31(3):288-92.

19. Yun HR, Koh HK, Kim SS, et al. FcgammaRlla/llla polymorphism and its association with clinical manifestations in Korean lupus patients. Lupus. 2001;10(7):466-72.

20. Siriboonrit U, Tsuchiya N, Sirikong M, et al. Association of Fcgamma receptor IIb and IIIb polymorphisms with susceptibility to systemic lupus erythematosus in Thais. Tissue Antigens. 2003;61(5):374-83.

21. Hatjiharissi E, Xu L, Santos DD, et al. Increased natural killer cell expression of CD16, augmented binding and ADCC activity to rituximab among individuals expressing the Fc\{gamma\}RIlla-158 VN and V/F polymorphism. Blood. 2007;110(7):2561-4.

22. Johansson SE, Rollman E, Chung AW, et al. NK cell function and antibodies mediating ADCC in HIV-1-infected viremic and controller patients. Viral Immunol. 2011;24(5):359-68.

23. Chung AW, Navis M, Isitman G, et al. Activation of NK cells by ADCC antibodies and HIV disease progression. J Acquir Immune Defic Syndr. 2011; 58(2):127-31.

24. Chung AW, Navis M, Isitman G, et al. Activation of NK cells by ADCC responses during early HIV infection. Viral Immunol. 2011;24(2):171-5.

25. Stratov I, Chung A, Kent SJ. Robust NK cell-mediated human immunodeficiency virus (HIV)-specific antibody-dependent responses in HIVinfected subjects. J Virol. 2008;82(11):5450-9.

26. Isitman G, Chung AW, Navis M, et al. Pol as a target for antibody dependent cellular cytotoxicity responses in HIV-1 infection. Virology. 2011;412(1):110-6.

27. Alter G, Teigen N, Davis BT, et al. Sequential deregulation of NK cell subset distribution and function starting in acute HIV-1 infection. Blood. 2005; 106(10):3366-9.

28. Ward J, Barker E. Role of natural killer cells in HIV pathogenesis. Current HIV/ AIDS Rep. 2008;5(1):44-50.

29. Meletiadis J, Walsh TJ, Choi EH, et al. Study of common functional genetic polymorphisms of FCGR2A, 3A and 3B genes and the risk for cryptococcosis in HIV-uninfected patients. Med Mycol. 2007;45(6):513-8.

30. Poonia B, Kijak GH, Pauza CD. High affinity allele for the gene of FCGR3A is risk factor for HIV infection and progression. PLoS One. 2010;5(12):e15562.

31. Hans VM, Mehta DS. Genetic polymorphism of Fcgamma-receptors Ila, Illa and IIIb in south Indian patients with generalized aggressive periodontitis. J Oral Sci. 2011;53(4):467-74.

32. Kimura K, Kobayashi D, Hatoyama S, et al. Effects of FCGRIIlla-158V/F polymorphism on antibody-dependent cellular cytotoxicity activity of adalimumab. APMIS Acta Pathol Microbiol Immunol Scand. 2017;125(12):1102-7.

33. International HapMap C. The International HapMap Project. Nature. 2003; 426(6968):789-96.

34. Leppers-van de Straat FG, van der Pol WL, Jansen MD, et al. A novel PCRbased method for direct Fc gamma receptor Illa (CD16) allotyping. J Immunol Methods. 2000;242(1-2):127-32.

35. Treon SP, Hansen M, Branagan AR, et al. Polymorphisms in FcgammaRIIIA (CD16) receptor expression are associated with clinical response to rituximab in Waldenstrom's macroglobulinemia. J Clin Oncol Off J Am Soc Clin Oncol. 2005;23(3):474-81.

36. Anolik JH, Campbell D, Felgar RE, et al. The relationship of FcgammaRllla genotype to degree of $\mathrm{B}$ cell depletion by rituximab in the treatment of systemic lupus erythematosus. Arthritis Rheum. 2003;48(2):455-9.

37. Veeramani $S$, Wang SY, Dahle C, et al. Rituximab infusion induces NK activation in lymphoma patients with the high-affinity CD16 polymorphism. Blood. 2011;118(12):3347-9.

38. Chaudhuri RP, Neogi U, Rao SD, et al. Genetic factors associated with slow progression of HIV among perinatally-infected Indian children. Indian Pediatr. 2014;51(10):801-3.

39. Gupta A, Padh H. Analysis of CCR5 and SDF-1 genetic variants and HIV infection in Indian population. Int J Immunogenet. 2015;42(4):270-8.

40. Sobieszczyk ME, Lingappa JR, McElrath MJ. Host genetic polymorphisms associated with innate immune factors and HIV-1. Curr Opin HIV AIDS. 2011; 6(5):427-34. 
41. Westrop SJ, Cocker ATH, Boasso A, et al. Enrichment of HLA types and single-nucleotide polymorphism associated with non-progression in a strictly defined cohort of HIV-1 controllers. Front Immunol. 2017;8:746.

42. Lehrnbecher TL, Foster CB, Zhu S, et al. Variant genotypes of FcgammaRIIIA influence the development of Kaposi's sarcoma in HIV-infected men. Blood. 2000;95(7):2386-90.

43. Naranbhai V, Altfeld M, Karim SS, et al. Changes in natural killer cell activation and function during primary HIV-1 infection. PLoS One. 2013;8(1): e53251.

\section{Publisher's Note}

Springer Nature remains neutral with regard to jurisdictional claims in published maps and institutional affiliations.

Ready to submit your research? Choose BMC and benefit from:

- fast, convenient online submission

- thorough peer review by experienced researchers in your field

- rapid publication on acceptance

- support for research data, including large and complex data types

- gold Open Access which fosters wider collaboration and increased citations

- maximum visibility for your research: over $100 \mathrm{M}$ website views per year

At BMC, research is always in progress.

Learn more biomedcentral.com/submissions 